\title{
Changes in the mechanical properties of the longitudinal and circular muscle tissues of the rat myometrium during gestation
}

\author{
Hidetaka Izumi
}

Department of Pharmacology, Faculty of Medicine, Kyushu University, Fukuoka 812, Japan

1 Changes in the mechanical properties of the longitudinal and circular muscle tissues of the rat myometrium during gestation were investigated.

2 In isolated longitudinal and circular muscles of the rat myometrium, spontaneous contractions and contractions per unit cross-sectional area induced by $128 \mathrm{mM} \mathrm{K}^{+}$and $1 \times 10^{-5} \mathrm{M}$ acetylcholine $(\mathrm{ACh})$ increased with the progress of gestation. These increases appeared in longitudinal muscles to a greater extent than in circular muscles.

3 ACh induced the largest contraction for both intact muscle tissues, at all stages of gestation. In both muscle layers, the ACh-induced contraction reached the same amplitude as the $1 \times 10^{-5} \mathrm{M} \mathrm{Ca}$-induced contraction of skinned muscles, except for the longitudinal muscle at the 22nd day of gestation.

4 In Ca-free solution containing $2 \mathrm{mM}$ EGTA, ACh produced contraction in both intact muscle tissues at all stages and the amplitude was increased during the progress of gestation, whereas the Kinduced and spontaneous contractions ceased.

5 In saponin-treated skinned muscles of both layers, the free $\mathrm{Ca}$ concentration required to produce contraction was lowered, the maximum amplitudes of the contraction were increased and the $\mathrm{pCa}$ tension relationships shifted to the left during the progress of gestation.

6 The results indicate that during the progress of gestation, Ca sensitivity of the contractile proteins and mechanical responses to agonists increased and that the properties of the intracellular Ca store site were also altered in both muscle layers.

\section{Introduction}

In uterine smooth muscle cells, calcium $(\mathrm{Ca})$ plays an essential role in triggering contractions, as observed in skeletal, cardiac and other visceral smooth muscles (Ebashi \& Endo, 1968; Abe, 1971; Devine et al., 1972; Endo, 1977; Daniel et al., 1979; Adelstein \& Eisenberg, 1980; Kuriyama et al., 1982). Ca for the contraction is due to influx (extracellular source) and release from cellular store sites (intracellular source; Edman \& Schild, 1962; Lalanne et al., 1984). Spontaneously generated and depolarization- or agonist-induced contractions of the myometrium are closely related to the membrane activity and also to the extracellular $\mathrm{Ca}$ concentration (Abe, 1971; Kuriyama \& Suzuki, 1976a,b; Kishikawa, 1981). For example, during the progress of gestation, the resting membrane potential of longitudinal muscle cells of the rat myometrium inceases up to the last stage of gestation and decreases at term (Casteels \& Kuriyama, 1965). The shape of the action potential in both longitudinal and circular muscles of the myometrium also changes during gestation, and shapes of the action potential differ between the longitudinal and circular muscle membrane during gestation, except for the last stage and during parturition (Kawarabayashi \& Osa, 1976; Osa \& Kawarabayashi, 1977; Osa \& Watanabe, 1978; Anderson et al., 1981; Osa et al., 1981; Osa \& Ogasawara, 1983; Osa et al., 1983). These changes in membrane properties may modify the Ca-influx of uterine smooth muscle during gestation.

Furthermore, there is evidence that cell volume, the amount of contractile proteins and the intracellular organelles per cell volume of uterine smooth muscle cells increases during gestation (Mattos et al., 1967; Michael \& Schofield, 1969; Devine et al., 1972). Recently, Matsui et al. (1983) reported that the activity of myosin light chain kinase and the total amount of 
calmodulin in the rabbit myometrium are increased during the progress of gestation. These two substances are essential factors for production of smooth muscle contraction. Therefore, the contractile force or the Casensitivity of the contractile protein would be modified with progress in gestation (Adelstein \& Eisenberg, 1980).

In the present experiments, attempts were made to investigate the gestational changes of the contractile forces evoked by excess concentrations of $\mathbf{K}$ or by acetylcholine ( $\mathrm{ACh})$ in intact muscle tissues and by various concentrations of $\mathrm{Ca}$ in saponin-treated skinned muscles for both longitudinal and circular muscle layers. The results are discussed in relation to the gestational changes of the free $\mathrm{Ca}$ concentration in the myoplasm, in both muscle layers.

\section{Methods}

Virgin female rats of the Wistar-King A line (10-16 weeks after birth; $180-240 \mathrm{~g}$ ) were kept at $19-21^{\circ} \mathrm{C}$ under natural light cycles. For an assessment of oestrous state, vaginal smears were taken daily at about $09 \mathrm{~h} 00 \mathrm{~min}$, and the proestrous rats were placed overnight with adult male rats. The first day of the pregnancy was estimated from the smear test, i.e. oestrous pattern of smear with the presence of sperm (Kishikawa, 1981). Most young were born between the evening of the 22nd day and the morning of the 23rd day. Animals were used at early (8-10th days), middle (17-19th days) and final (22nd day) stages of gestation.

The dams were stunned and bled from the carotid artery; excised uteri were dissected immediately from the mesometrium side, in the longitudinal direction and foetuses and placentas were carefully removed. An overdose of ether was given to the foetuses. Myometrial tissue was prepared in Krebs solution at room temperature while bubbling with $97 \% \mathrm{O}_{2}$, and $3 \% \mathrm{CO}_{2}$. To prepare the longitudinal muscle strips, the circular muscle layer together with the endometrium was carefully removed, with the aid of a dissection microscope; for the circular muscle preparations, the endometrium was initially dissected followed by removal of the longitudinal muscle layer.

\section{Recording of mechanical responses}

A segment of tissue $(0.05-0.07 \mathrm{~mm}$ in width, $0.02-0.03 \mathrm{~mm}$ in thickness and about $0.5 \mathrm{~mm}$ in length) was mounted horizontally in an experimental recording chamber with a capacity of $0.9 \mathrm{ml}$, and the tissue was superfused with Krebs solution. Both ends of the preparation were fixed between pieces of Scotch double-sided adhesive tape (3M Co, St Paul, MN), and isometric tension was recorded with a strain gauge transducer (U-gauge, Shinko, Tokyo). A resting tension of less than $10 \mathrm{nN}$ was applied to obtain the maximum contractile force produced by $\mathrm{K}$ or acetylcholine and to eliminate possible involvement of elastic components on the tension measurements. Before the experiments, the width and thickness of the preparations were measured with a microscope at magnification of 200 and the cross-sectional area was calculated, assuming an ellipsoidal cross-section (Iino, 1981). The test solution was applied by jetting from one end of the chamber and the solution in the chamber was siphoned from the other end. This method enabled application of the test solution within $2 \mathrm{~s}$. To eliminate artifacts due to the sudden change in level of the solution in the chamber, recovery of the recording pen to the original level was checked prior to the start of the experiment (Itoh et al., 1981). In the intact muscle tissues, the maximum responses evoked by $128 \mathrm{mM} \mathrm{K}$ or $1 \times 10^{-5} \mathrm{M}$ acetylcholine (ACh) were not affected by propranolol $\left(1 \times 10^{-6} \mathrm{M}\right)$, phentolamine $\left(1 \times 10^{-7} \mathrm{M}\right)$ or guanethidine $\left(1 \times 10^{-6} \mathrm{M}\right)$.

To assess the Ca sensitivity, the tissues were skinned with saponin, according to the method described by Itoh et al. (1981). After a K- or ACh-induced contraction of the intact muscle had been recorded, the bathing solution was replaced with a relaxing solution containing $111 \mathrm{mM}-\mathrm{K}$ methanesulphonate, $20 \mathrm{mM}$ Tris-maleate, $5 \mathrm{mM}-\mathrm{Mg}$ methanesulphonate, $5 \mathrm{mM}$ ATP (10 mM-Na as $\mathrm{Na}_{2}$ ATP) and $4 \mathrm{mM}$ ethyleneglycol-bis-( $\boldsymbol{\beta}$-aminoethylether)- $\mathbf{N}, \mathrm{N}^{\prime}$-tetraacetic acid (EGTA) at pH 6.8. The tissue was then left for 20 to $25 \mathrm{~min}$ in the relaxing solution containing $50 \mu \mathrm{g} \mathrm{ml}^{-1}$ saponin (ICN), and washed again with the relaxing solution until the tension became constant at about zero. Immediately before application of a Ca-containing solution, the preparation was superfused with the relaxing solution. To investigate the effects of $\mathrm{Ca}$ on the contractile proteins, the pCa-tension curve was plotted. Various concentrations of $\mathrm{Ca}$ were prepared by adding appropriate amounts of $\mathrm{Ca}$-methanesulphonate to EGTA. The apparent binding constant of EGTA for Ca was considered to be $1 \times 10^{6} \mathrm{M}^{-1}$ at pH 6.8 at $25^{\circ} \mathrm{C}$ (lino, 1981; Itoh et al., 1981; Saida, 1982). The $\mathrm{pH}$ of the relaxing and various Ca solutions was kept at 6.8 by isosmotically replacing the appropriate amount of $\mathrm{K}$ methanesulphonate with $\mathrm{KOH}$. As deterioration of the skinned muscle occurred at temperatures over $25^{\circ} \mathrm{C}$, the temperature in the intact and skinned muscle tissues was kept at $25^{\circ} \mathrm{C}$ (Iino, 1981; Itoh et al., 1981).

\section{Solutions}

The ionic composition of the Krebs solution was as follows (mM): $\mathrm{Na}^{+} 137.4, \mathrm{~K}^{+} 5.9, \mathrm{Mg}^{2+} 1.2, \mathrm{Ca}^{2+} 2.6$, $\mathrm{HCO}_{3}{ }^{-} 15.5, \mathrm{H}_{2} \mathrm{PO}_{4}{ }^{-} 1.2, \mathrm{Cl} 134.0$ and glucose 11.5; $97 \% \mathrm{O}_{2}$ with $3 \% \mathrm{CO}_{2}$ was bubbled into the solution. 
High- $[\mathrm{K}]_{\mathrm{o}}$ solution was prepared by replacing $\mathrm{NaCl}$ with $\mathrm{KCl}$, isosmotically; Ca-free solution was prepared by removal of $\mathrm{CaCl}_{2}$ from the solution and addition of $2 \mathrm{mM}$ EGTA. The $\mathrm{pH}$ of the solution was 7.2.

\section{Drugs}

Chemicals used in the present experiments were acetylcholine chloride (Sigma), saponin (ICN Pharmac.) and EGTA (Dozin).

\section{Statistics}

The results obtained were expressed as the mean \pm s.e.mean. The $n$ values represent the numbers of animals. The statistical significance was assessed by Student's $t$ test, and paired comparisons were made when appropriate.

\section{Results}

Changes in the mechanical response of longitudinal and circular muscle tissues to $128 \mathrm{mM} \mathrm{K}$ or acetylcholine

In small longitudinal and circular muscle preparations (the cross-sectional area ranged between $0.91 \times 10^{-3} \mathrm{~mm}^{2}$ and $1.91 \times 10^{-3} \mathrm{~mm}^{2}$ ), spontaneous contractions occurred at all stages of gestation. Application of $128 \mathrm{mM} \mathrm{K}$ or $10^{-5} \mathrm{M}$ ACh produced contractions in both longitudinal and circular muscle tissues, at all stages of the pregnancy. Figure 1 shows the spontaneous contraction, and contractions induced by $128 \mathrm{mM} \mathrm{K}$ and $10^{-5} \mathrm{M} \mathrm{ACh}$ per unit crosssectional area $\left(\mathrm{mN} \mathrm{mm}^{-2}\right)$ at four different stages (non-pregnant, 8-10th, 17-19th and 22nd days of gestation).

When amplitudes of contraction between the longitudinal and circular muscles were compared, there
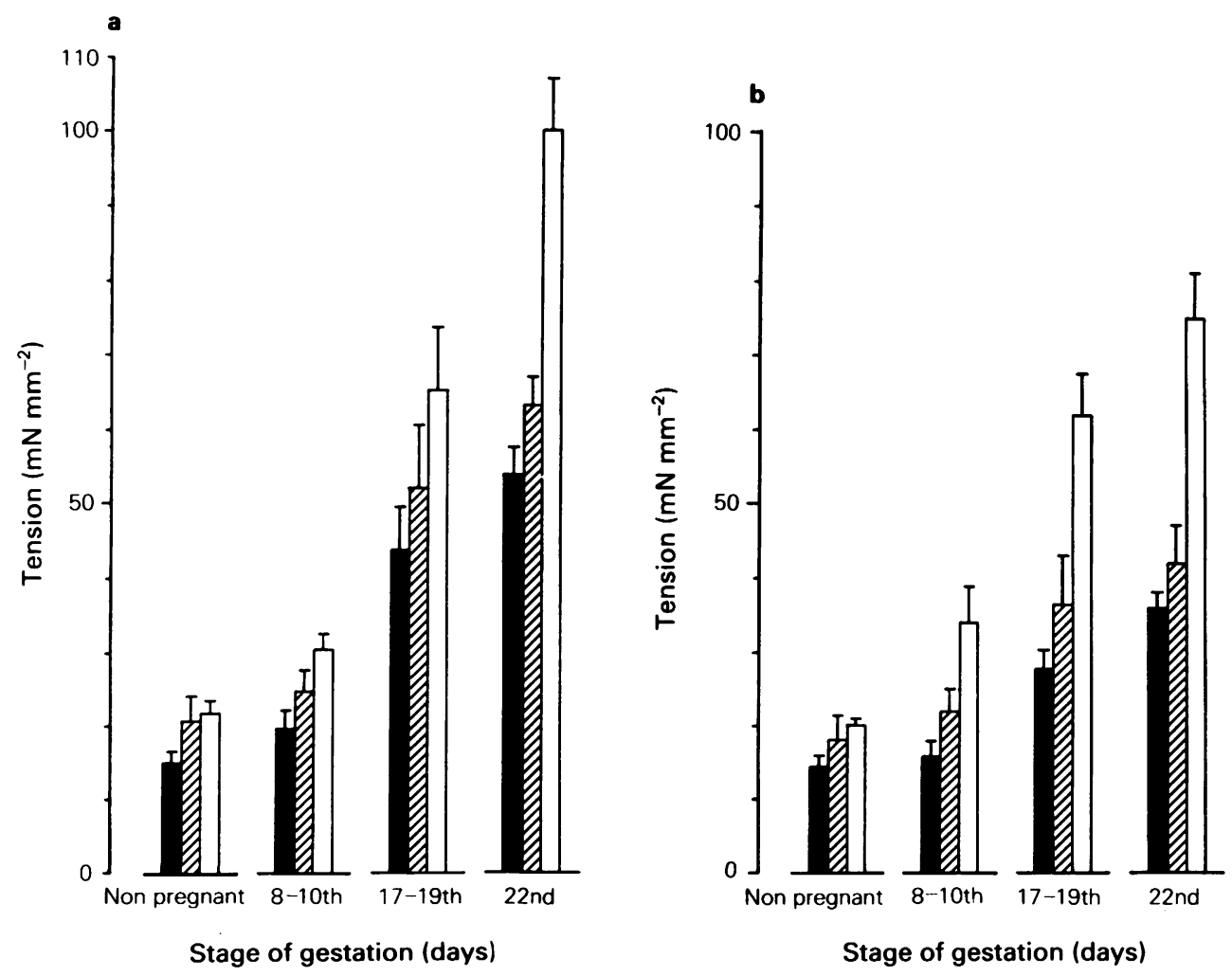

Figure 1 The tension of spontaneous contraction (solid columns), $128 \mathrm{~mm} \mathrm{~K}$-induced contraction (hatched columns) and $1 \times 10^{-5} \mathrm{M}$ acetylcholine-induced contraction (open columns) per unit cross-sectional area in longitudinal (a) and circular (b) muscle tissues of the rat myometrium at four different stages of gestation. Values are mean with vertical lines indicating s.e., $n=5$. 
were no significant differences in the non-pregnant stage, the early stage and the middle stage of gestation $(P>0.05$ at each stages, $n=5)$. However, contractions were significantly larger in the longitudinal than in the circular muscle, at the last stage of gestation $(P<0.005)$. When the amplitudes of contractions were compared during different stages of gestation, the spontaneous, $\mathrm{K}$ - and $\mathrm{ACh}$-induced contractions in both longitudinal and circular muscles were significantly larger at the middle stage of gestation than at the early stage $(P<0.01)$, and the amplitude was further enhanced during the last stage of gestation, as compared to the middle stage of gestation $(P<0.005)$, or the non-pregnant stage. In non-pregnant rats, myometria excised during oestrous and nonoestrous states had similar spontaneous and evoked contractions.

In both longitudinal and circular muscle layers, the $\mathrm{K}$-induced contractions were not significantly larger than the spontaneous contractions, for any given stage of gestation $(P>0.05)$. The contractions induced by ACh $\left(1 \times 10^{-5} \mathrm{M}\right)$ were also not significantly larger than the spontaneous contractions for both muscle layers in the non-pregnant and early stage of gestation, nor for the longitudinal muscle tissues of the middle stage of gestation $(P>0.05)$. However, the response was increased in the circular muscle tissue at the middle stage $(P<0.01)$, and ACh-induced contractions were larger than the spontaneous or $\mathrm{K}$-induced contractions of both layers in the last stage of gestation $(P<0.005)$.

Figure 2 shows actual records of the effects of $128 \mathrm{mM} \mathrm{K}$ and $\mathrm{ACh}\left(1 \times 10^{-5} \mathrm{M}\right)$ on the longitudinal and circular muscle layers of myometria obtained from non-pregnant rats and at the 22nd day of gestation. In the non-pregnant stage, $1 \times 10^{-5} \mathrm{M} \mathrm{ACh}$ and $128 \mathrm{mM} \mathrm{K}$ induced contractions of similar amplitude, whereas on the 22nd day of gestation, $1 \times 10^{-5} \mathrm{M}$ ACh produced larger contractions than those produced by $128 \mathrm{mM} \mathrm{K}(1.58$ and 1.78 times greater $(n=5)$ for longitudinal and circular muscles, respectively).

The effects of various concentrations of ACh on the longitudinal and circular muscle tissues at different stages of gestation are shown in Figure 3. For longitudinal muscle strips $1 \times 10^{-8} \mathrm{M}$ ACh produced no contraction of strips from non-pregnant, early or middle stages of gestation but produced $50 \%$ of the maximum response in late pregnancy. In circular muscle, strips at all stages of pregnancy were contracted by $1 \times 10^{-8} \mathrm{M}$ ACh. Responses of both muscle tissues to ACh were consistently increased during the progress of gestation.
Non pregnant

a

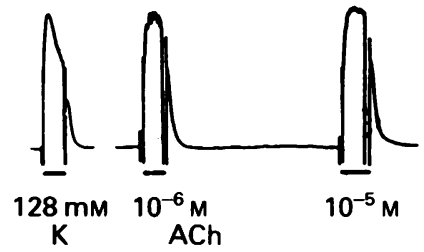

b

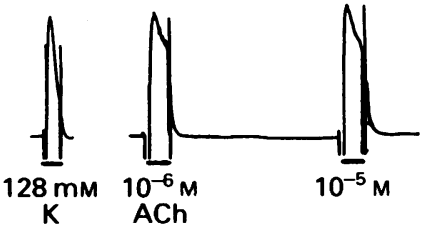

22nd day

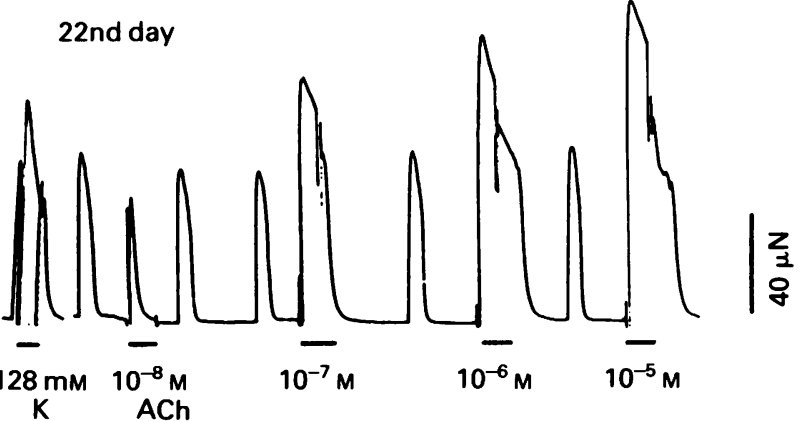

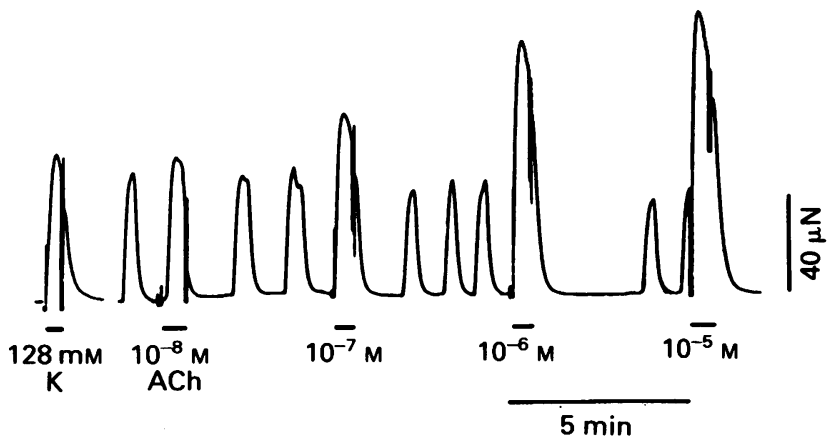

Figure 2 Effects of $128 \mathrm{mM} \mathrm{K}$ or various concentrations of acetylcholine (ACh) on the myometria from non-pregnant and 22nd day pregnant rats: (a) longitudinal muscle tissues; (b) circular muscle tissues. 


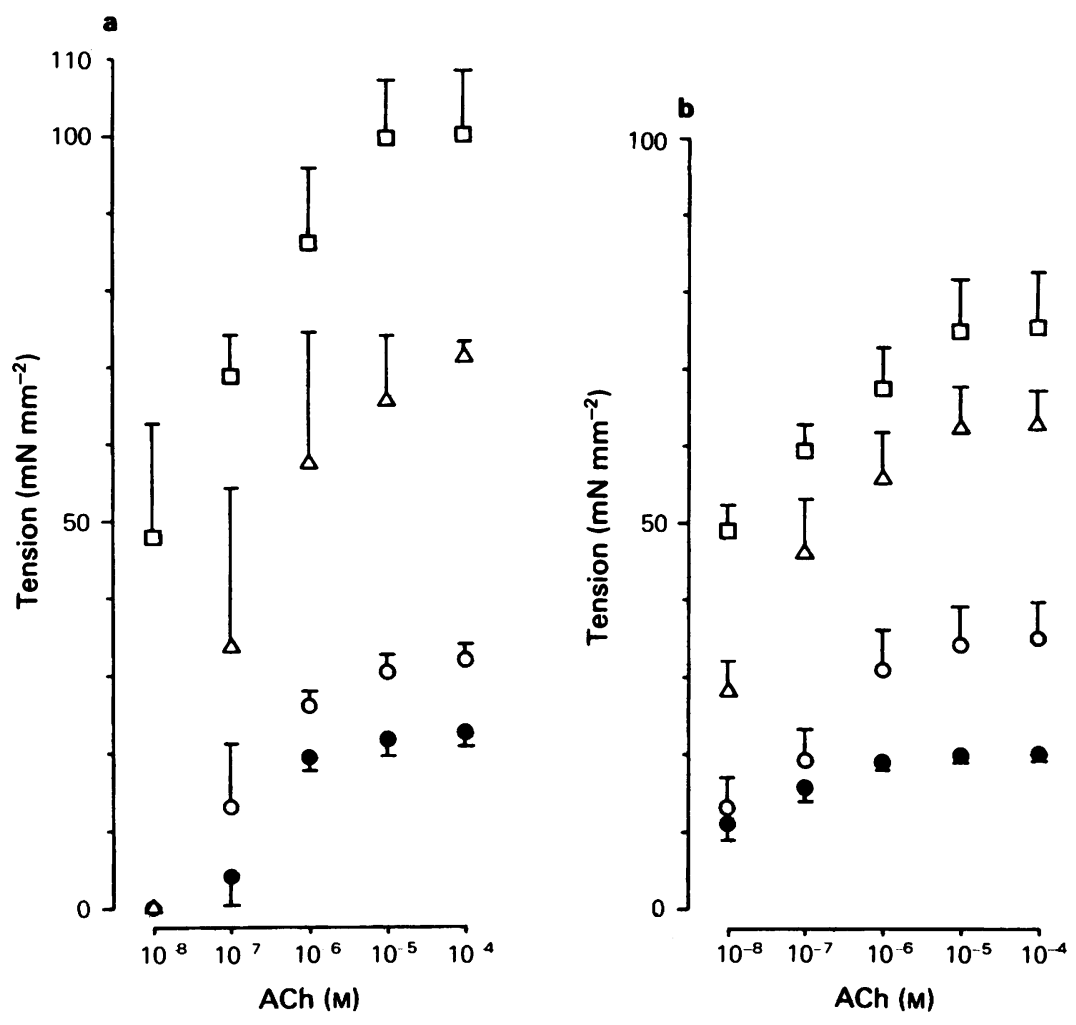

Figure 3 Effects of various concentrations of acetylcholine (ACh) on the longitudinal (a) and circular (b) muscle tissues at four different states of the myometria: (O) non-pregnant; $(O)$ 8-10th day; $(\Delta) 17-19$ th day; (D) 22nd day. Values are mean with vertical lines indicating s.e., $n=3-5$.

Non pregnant

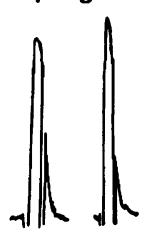

$28 \overline{\mathrm{mMK}} 10^{-5} \mathrm{MACh}$
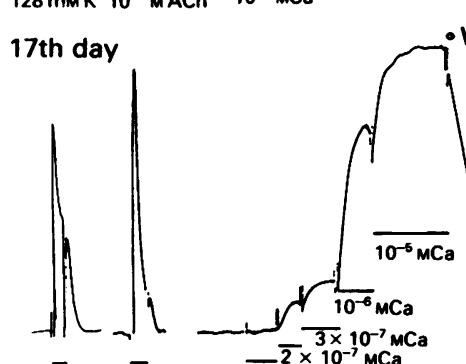

$128 \overline{\mathrm{mM} K} \quad 1 \overline{0}^{-5} \mathrm{MACh} \quad \overline{10^{-7}} \overline{\mathrm{MCa}}$

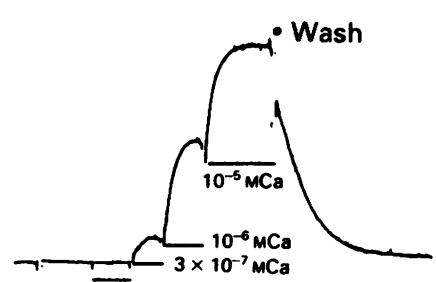

$2 \times 10^{-7} \mathrm{MCa}$

- Wash

Figure 4 Effects of various concentrations of free $\mathrm{Ca}$ on the longitudinal (a) and circular (b) skinned muscle tissues. Before skinning with $\left(50 \mu \mathrm{g} \mathrm{ml}^{-1}\right.$ saponin) for $25 \mathrm{~min}, 128 \mathrm{mM} \mathrm{K}$ and $1 \times 10^{-5} \mathrm{M} \mathrm{ACh}$ were applied. After skinning the tissue, $10^{-7}-10^{-5} \mathrm{Ca}$ was applied cumulatively: (a) non-pregnant and 17th day of pregnancy; (b) non-pregnant and 22nd day of pregnancy. 


\section{Changes in the Ca sensitivity during the progress of gestation}

Before application of saponin, $\left(50 \mu \mathrm{g} \mathrm{ml}^{-1}\right)$ as described in Methods, the amplitudes of the $\mathrm{K}$ - and $\mathrm{ACh}$ induced contractions were recorded in order to compare the mechanical responses in intact and skinned muscle tissues. As shown in Figure 4, to produce the contraction in skinned muscles, various concentrations of free $\mathrm{Ca}$ were applied cumulatively $\left(10^{-7} \mathrm{M}-10^{-5} \mathrm{M} \mathrm{Ca}\right)$.

Figure 5A shows the free $\mathrm{Ca}(\mathrm{pCa})$-tension relationship (non-pregnant, 17-19th and 22nd days of gesta- tion). The $1 \times 10^{-5} \mathrm{M} \mathrm{Ca}$-induced contraction at each stage was normalized as 1.0 . Increasing the concentration of free $\mathrm{Ca}$ to $1 \times 10^{-4} \mathrm{M}$ did not change the amplitude over that produced by $1 \times 10^{-5} \mathrm{M}$. These results could be summarized as follows; (i) the minimum concentration of $\mathrm{Ca}$ required to produce a contraction was $3 \times 10^{-7} \mathrm{M}$ in both skinned longitudinal and circular muscle tissues of non-pregnant rats. During the progress of pregnancy, the minimum concentration required was reduced to $2 \times 10^{-7} \mathrm{M}$, in both longitudinal and circular muscle tissues on the $17-19$ th days of gestation and $1 \times 10^{-7} \mathrm{M}$ on the $22 \mathrm{nd}$ day of gestation. (ii) The values of the $\mathrm{ED}_{50}$ were also
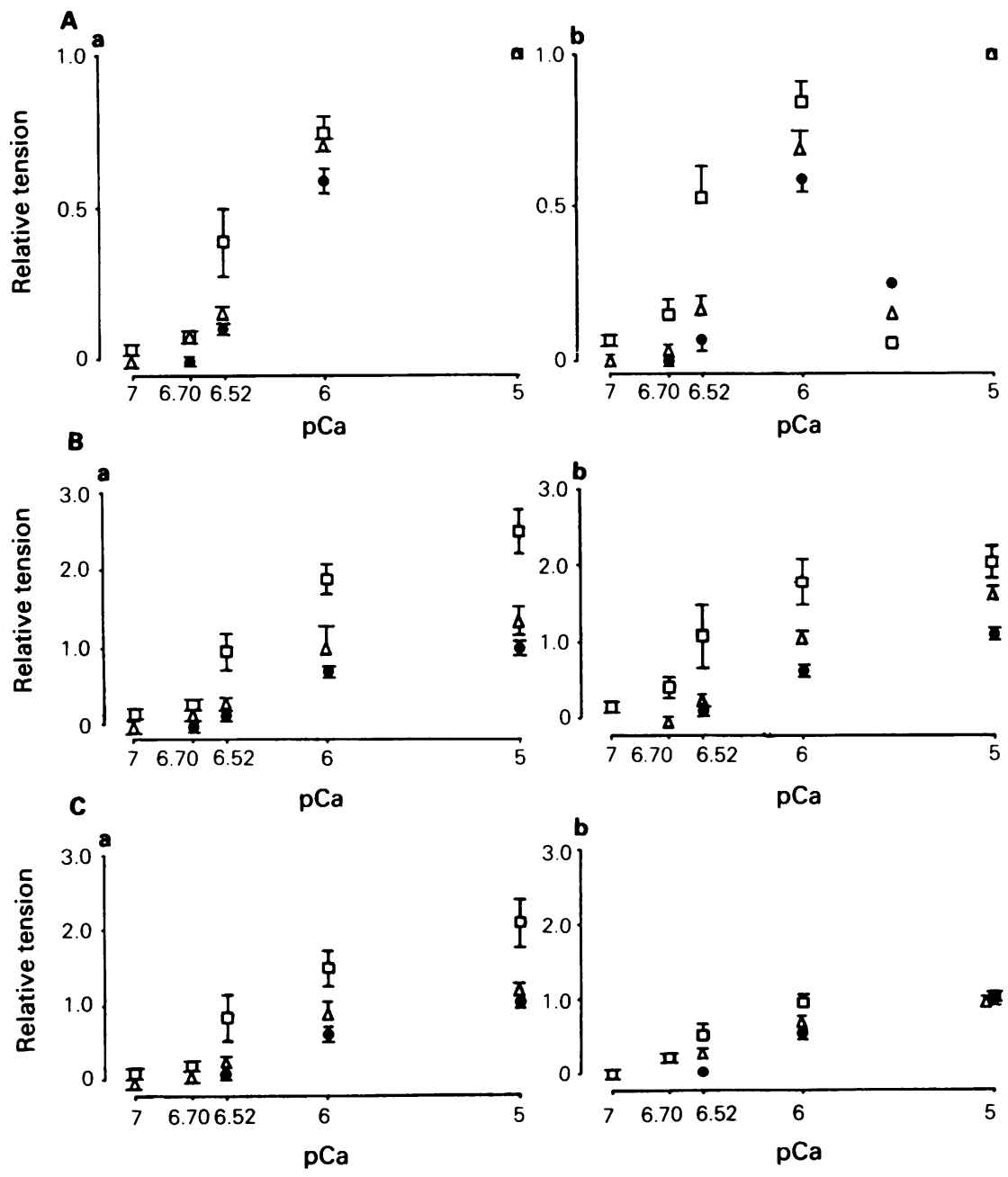

Figure 5 The pCa-tension relationships observed in skinned longitudinal (a) and circular (b) rat myometrial muscle tissues. (A) for each tissue, the contractions are relative to the contractions induced by $1 \times 10^{-5} \mathrm{M} \mathrm{Ca}$. (B) Contractions relative to those induced in the intact muscle by $128 \mathrm{mM} \mathrm{K}$. (C) Contractions relative to those induced in the intact muscle by $1 \times 10^{-5} \mathrm{M}$ acetylcholine. $(O)$ Non-pregnant; $(\Delta) 17-19$ th day; $(\square) 22$ nd day. Values are mean with vertical lines indicating s.e. $n=3-8$. 
decreased (in longitudinal muscles, $8.26 \pm 0.68 \times 10^{-7} \mathrm{M} \mathrm{Ca}$ at the non-pregnant stage, $6.62 \pm 0.44 \times 10^{-7} \mathrm{M} \mathrm{Ca}$ at the 17-19th days of gestation, $3.44 \pm 0.62 \times 10^{-7} \mathrm{M} \mathrm{Ca}$ at the $22 \mathrm{nd}$ day of gestation; in circular muscles, $8.31 \pm 0.72 \times 10^{-7} \mathrm{M}$ $\mathrm{Ca}$ (non-pregnant), $6.68 \pm 0.52 \times 10^{-7} \mathrm{M} \quad \mathrm{Ca}$ (17-19th days), $3.33 \pm 0.32 \times 10^{-7} \mathrm{M} \mathrm{Ca}(22 \mathrm{nd}$ day), $n=3-8$, mean \pm s.e.mean). Therefore the results indicate that with progress in gestation, the $\mathrm{pCa}$ tensionrelation curve shifted to the left. This means that the Ca sensitivity (including the absolute tension development per cross-sectional area of contractile proteins) is increased in both longitudinal and circular muscle tissues.

Figure 5B shows the pCa-tension relationship, plotted with the $\mathrm{K}$-induced contraction at each stage of gestation normalized as 1.0. The results are summarized as follows: (i) in both longitudinal and circular muscle tissues at the non-pregnant stage and the 17-19th days of gestation, there was no significant differences between the $128 \mathrm{mM} \mathrm{K}$-induced contraction in intact muscle tissue and the maximum $\mathrm{Ca}$ induced contraction (at $1 \times 10^{-5} \mathrm{M}$ ) in skinned muscle tissues $(P>0.05)$. However, there were significant increases in the amplitude of the $\mathrm{Ca}$-induced contraction in both muscle tissues on the 22nd day of gestation $(P<0.01)$. (ii) When the free $\mathrm{Ca}$ concentrations required to evoke the $128 \mathrm{mM} \mathrm{K}$-induced contraction were estimated from the pCa-tension curve at each stage of gestation, the values in the longitudinal muscle layers were $1.95 \pm 0.2 \times 10^{-6} \mathrm{M} \mathrm{Ca}$ (non-pregnant), $8.64 \pm 1.41 \times 10^{-7} \mathrm{M} \mathrm{Ca}$ (17-19th days) and $4.20 \pm 0.63 \times 10^{-7} \mathrm{M}$ Ca (22nd day) of gestation; in the circular muscle layer, they were $2.44 \pm 0.22 \times 10^{-6} \mathrm{M} \quad \mathrm{Ca}$ (non-pregnant), $9.27 \pm$ $0.53 \times 10^{-7} \mathrm{M}$ Ca $(17$ th-19th days) and $3.68 \pm$ $0.74 \times 10^{-7} \mathrm{M}$ Ca (22nd day) $(n=3-8$, mean \pm s.e.mean). These results indicated that the estimated free $\mathrm{Ca}$ concentration evoked by $128 \mathrm{mM} \mathrm{K}$ decreased on both muscle layers in the progess of gestation.

Figure $5 \mathrm{C}$ shows the $\mathrm{pCa}$-tension relationship with the contraction induced by $1 \times 10^{-5} \mathrm{M}$ ACh normalized as 1.0 at each stage of gestation. These results indicate that (i) only in the longitudinal muscle layer at the 22nd day of gestation, was there a significant increase in the Ca-induced contraction (pCa 5) in skinned muscles over that evoked by ACh $\left(1 \times 10^{-5} \mathrm{M}\right)$ intact muscle $(P<0.01)$. The amplitude of the ACh-induced contraction was similar to the maximum contraction evoked by $1 \times 10^{-5} \mathrm{M} \mathrm{Ca}$ in the longitudinal muscles for the non-pregnant and the middle stage of gestation and in the circular muscles at all stages of gestation $(P>0.05)$. Therefore, the estimated free $\mathrm{Ca}$ concentration evoked by $\mathrm{ACh}$ decreased only at the 22nd day of gestation for longitudinal muscle layers. However, during the progress of gestation these changes of free $\mathrm{Ca}$ concen-

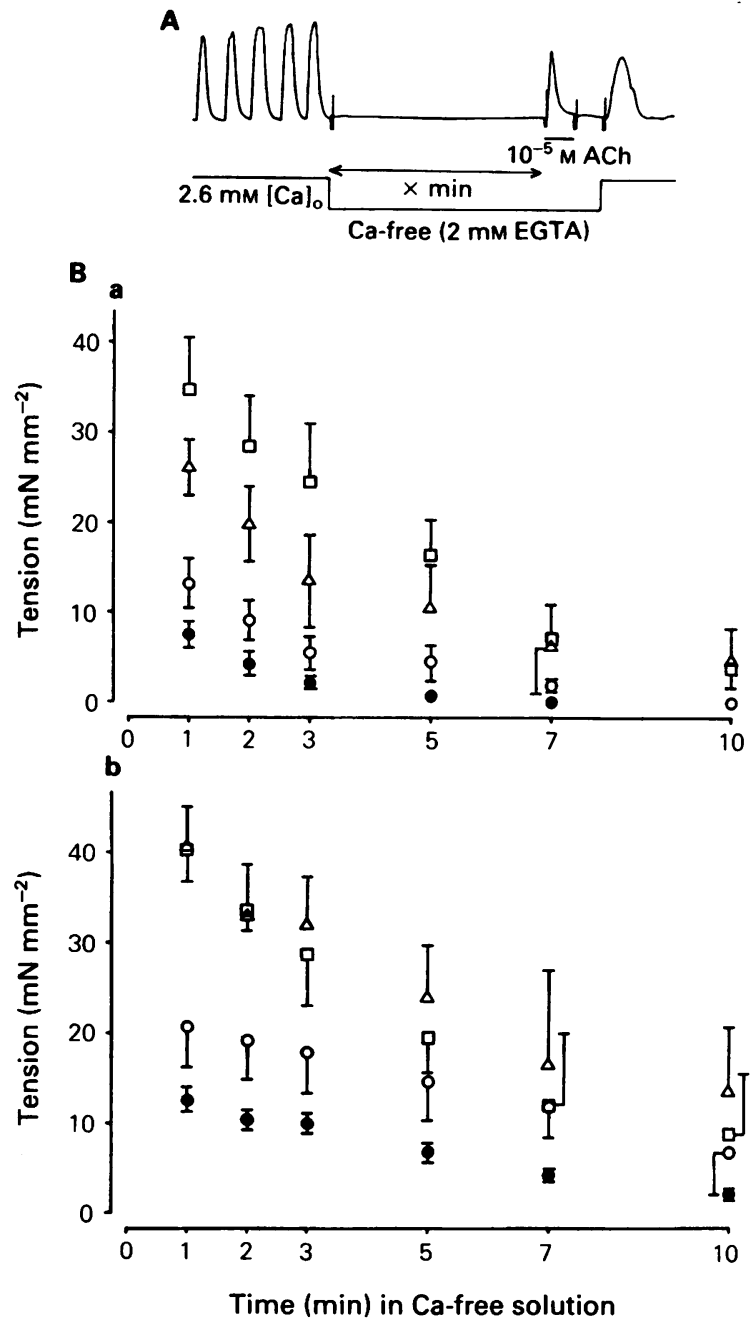

Figure 6 Effects of $1 \times 10^{-5} \mathrm{M}$ acetylcholine in Ca-free 2 mM EGTA containing solution on longitudinal (a) and circular (b) muscle tissues at four different states of the myometria: (O) non-pregnant; $(O)$ 8-10th day; $(\Delta)$ 17-19th day; () 22nd day. Acetylcholine was applied 1-10 min after exposure to Ca-free solutions. Values are mean with vertical lines indicating s.e. $n=3-6$.

tration for $\mathrm{ACh}$-induced contractions were smaller than those for $\mathrm{K}$-induced ones in both muscle layers.

\section{Effects of acetylcholine or $128 \mathrm{mM} \mathrm{K}$ on rat myometrium in Ca-free solution}

In Ca-free $2 \mathrm{mM}$ EGTA containing solution, ACh $\left(1 \times 10^{-5} \mathrm{M}\right)$ induced contraction in both muscle tissues but the amplitude of contraction in Ca-free 


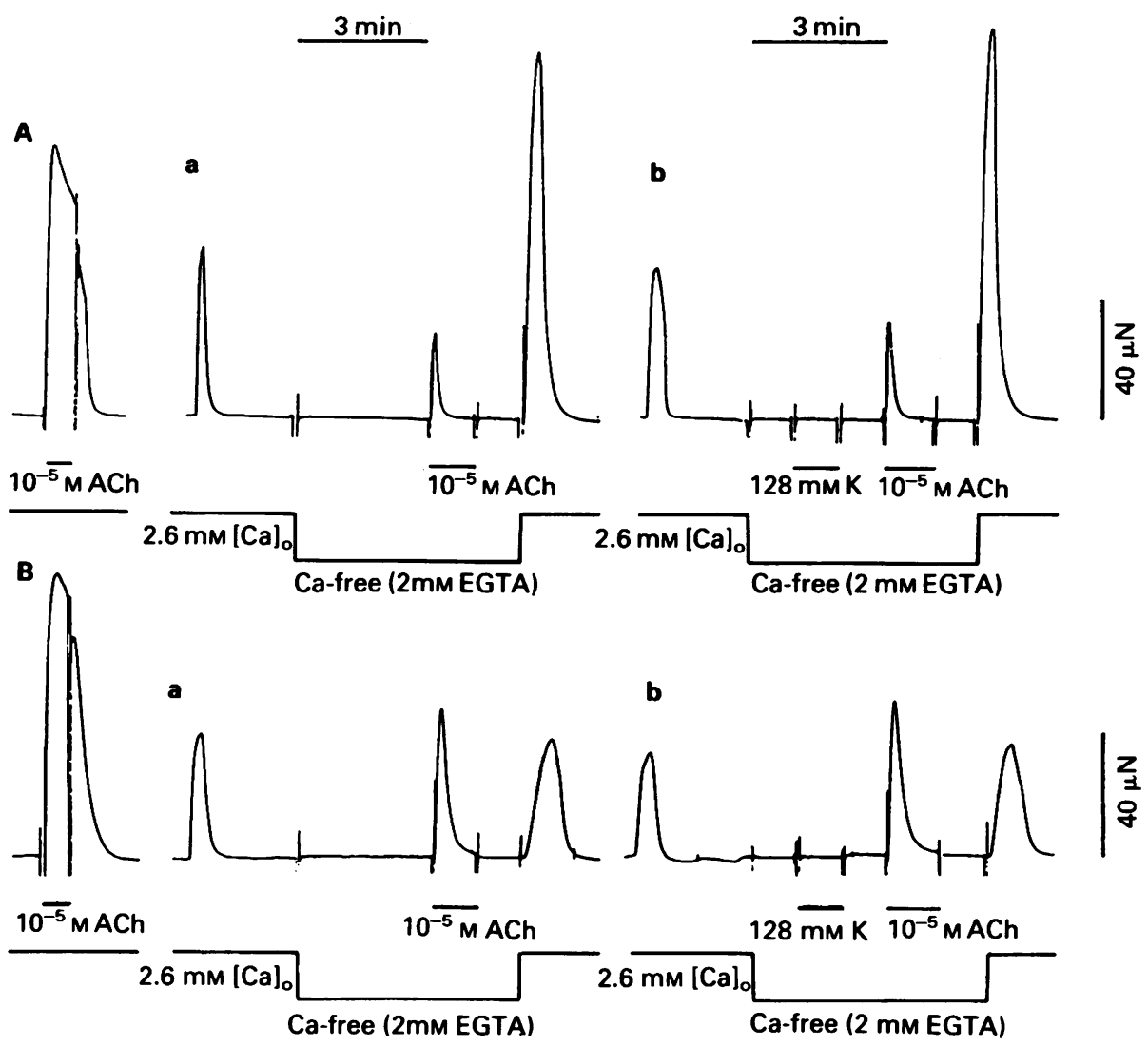

Figure 7 Effects of $1 \times 10^{-5} \mathrm{M}$ acetylcholine ( $\mathrm{ACh}$ ) (a), and successive applications of $128 \mathrm{mM} \mathrm{K}$ and $1 \times 10^{-5} \mathrm{M} \mathrm{ACh}$ (b) on the longitudinal (A) and circular (B) muscle tissues, in Ca-free 2 mM EGTA containing solution, obtained on the 22nd day of gestation. Unlabelled contractions were spontaneous.

solution decreased, time dependently after removal of $\mathrm{Ca}$, in tissues from both non-pregnant and pregnant rats. The time course of the amplitude of the $\mathrm{ACh}$ induced contraction in $\mathrm{Ca}$-free solution is shown in Figure 6. The reductions in amplitude for the nonpregnant stage and the early and middle stages of gestation were more rapid in the longitudinal than in the circular muscles.

A contraction could not be evoked by $\mathrm{K}$ in Ca-free solution containing $2 \mathrm{mM}$ EGTA. Therefore, the AChinduced contraction in Ca-free solution was thought to be produced by $\mathrm{Ca}$ released from intracellular

Table 1 Effects of $128 \mathrm{~mm} \mathrm{~K}$ on the acetylcholine-induced contraction in Ca-free 2 mM EGTA containing solution (experimental procedures were the same as shown in Figure 7 and also in the text)

\begin{tabular}{|c|c|c|c|c|c|c|}
\hline \multirow[t]{2}{*}{ Stages of gestation } & \multicolumn{2}{|c|}{$8-10$ th days } & \multicolumn{2}{|c|}{$17-19$ th days } & \multicolumn{2}{|c|}{ 22nd day } \\
\hline & Longitudinal & Circular & Longitudinal & Circular & Longitudinal & Circular \\
\hline $\begin{array}{l}\text { ACh-induced contraction } \\
\text { in Ca-free } \\
\text { solution }\left(\mathrm{mN} \mathrm{mm}^{-2}\right)\end{array}$ & $5.4 \pm 1.7$ & $17.8 \pm 4.4$ & $13.6 \pm 5.2$ & $32.0 \pm 5.5$ & $24.6 \pm 6.3$ & $28.6 \pm 5.5$ \\
\hline $\begin{array}{l}\text { ACh-induced contraction } \\
\text { after } 128 \mathrm{mM} \mathrm{K} \\
\text { treatment in Ca-free } \\
\text { solution }\left(\mathrm{mN} \mathrm{mm}^{-2}\right)\end{array}$ & $6.10 \pm 0.5$ & $16.9 \pm 0.9$ & $17.0 \pm 2.9$ & $27.2 \pm 1.0$ & $25.8 \pm 1.0$ & $25.2 \pm 4.0$ \\
\hline
\end{tabular}

Values are means \pm s.e.means; $n=3-8$ 
stores. When $\mathrm{ACh}$ was added a 2 nd time in Ca-free solution, no contraction was produced at all stages of gestation.

To investigate the interaction between excess $K$ and $\mathrm{ACh}$ for $\mathrm{Ca}$ release from intracellular store sites, the following experiments were carried out (Figure 7); Longitudinal (A) and circular (B) muscle tissues were exposed to $\mathrm{Ca}$-free solution for $5 \mathrm{~min}$; $\mathrm{ACh}$ was applied for $1 \mathrm{~min}$ following $3 \mathrm{~min}$ exposure in $\mathrm{Ca}$-free solution ( $\mathrm{Aa}$ and $\mathrm{Ba}$ ); the same tissues were again exposed to $5 \mathrm{~min} \mathrm{Ca}$-free solution and $128 \mathrm{mM} \mathrm{K}$ was applied for $1 \mathrm{~min}$ after $1 \mathrm{~min}$ exposure in Ca-free solution followed by $\mathrm{ACh}\left(1 \times 10^{-5} \mathrm{M}\right)$ for $1 \mathrm{~min}$ after $3 \mathrm{~min}$ exposure in $\mathrm{Ca}$-free solution ( $\mathrm{Ab}$ and $\mathrm{Bb}$ ). Following the application of $128 \mathrm{mM} \mathrm{K}$, the amplitude of the subsequently generated $\mathrm{ACh}$-induced contraction was identical to that evoked by $\mathrm{ACh}$ alone, in both longitudinal and circular muscle tissues (Table 1).

On the 22nd day of gestation, a large contraction (rebound contraction) was evoked on returning to $2.6 \mathrm{mM} \mathrm{Ca}$, after exposure to $\mathrm{Ca}$-free solution for $5 \mathrm{~min}$, in both muscle tissues. The amplitude of the rebound contraction in the longitudinal muscle was much the same as that of the Ca-induced contraction evoked by application of $1 \times 10^{-6} \mathrm{MCa}$ in skinned muscles but the amplitude of the rebound contraction in the circular muscle tissues was smaller than that evoked by $1 \times 10^{-5} \mathrm{MACh}$ in intact muscle tissues or $1 \times 10^{-6} \mathrm{M} \mathrm{Ca}$ in skinned muscles (Figure 7).

\section{Discussion}

Our findings indicate that, per unit cross-sectional area, spontaneous, $\mathrm{K}$ - and $\mathrm{ACh}$-induced contractions in intact muscles and the $1 \times 10^{-5} \mathrm{MCa}$-induced contractions in saponin-treated skinned muscles increased with the progress of gestation in both longitudinal and circular muscle layers. Furthermore, the Ca-sensitivity of contractile proteins, as estimated from the $\mathrm{pCa}$-tension relationship in chemically skinned muscles also increased during the progress of gestation, in both muscle layers. Mattos et al. (1967) and Michael \& Schofield (1969) have reported that during the progress of gestation, muscular hypertrophy occurred and this accompanied an increase in the contractile proteins and high energy phosphate, especially during the last half of pregnancy. An increase in the contractile proteins per $\mathrm{mg}$ tissue would increase the absolute contractile force per unit cross sectional area. Since calmodulin is a Ca-receptor of contractile proteins in smooth muscles, increases in calmodulin contents would increase the Ca-sensitivity of smooth muscle contractile proteins or the amplitude of contraction (Adelstein \& Eisenberg, 1980; Adelstein \& Klee, 1980; Rüegg et al., 1983).
Recently, Matsui et al. (1983) observed that the amount of calmodulin and activity of myosin lightchain kinase increased during gestation in the rabbit myometrium.

In the present experiments, the $\mathrm{Ca}$ sensitivity of the contractile protein was estimated from the saponintreated chemically skinned muscle. The criteria for successful skinning of the muscle tissue was as follows (Iino, 1981; Itoh et al., 1981): (i) the maximum Cainduced contraction in skinned muscle was the same as or larger than the $1 \times 10^{-5} \mathrm{M} \mathrm{ACh}$-induced contraction evoked in intact muscle; (ii) after inducing a contraction with $\mathrm{Ca}^{2+}$ in the saponin-treated tissues and replacing the relaxing solution with Krebs solution for 0.5 to $1 \mathrm{~h}$, application of $128 \mathrm{mM} \mathrm{K}$ or $1 \times 10^{-5} \mathrm{M}$ ACh should produce no contraction.

In this study, we observed changes in the amplitude of the $128 \mathrm{mM} \mathrm{K}$ - or ACh-induced contraction as an indicator of the depolarization- or agonist-induced contraction during the progress of gestation, respectively. The results indicate that the amount of free $\mathrm{Ca}$ provoked by high $\mathrm{K}$ differs at each stage of gestation as estimated from the amplitude of the Ca-induced contraction of chemically skinned muscles recorded at the corresponding stage of gestation. Since the high Kinduced contraction was markedly depressed in $\mathrm{Ca}$ free solution containing EGTA, this contraction may largely depend on voltage-dependent $\mathrm{Ca}$ influx. The volume of the sarcoplasmic reticulum and the mitochondria, which may be the sites of the intracellular $\mathrm{Ca}$ store, increased during gestation (Devine et al., 1972). Furthermore, the amount of calmodulin increased during gestation in rabbit myometrium (Matsui et al., 1983) and calmodulin increased the ATPase activity and the uptake of ${ }^{45} \mathrm{Ca}$ of plasma- and sarcoplasmic reticulum membrane particles in cardiac and smooth muscles (Daniel et al., 1979; Suematsu et al., 1984a). If these phenomena also occur in rat uterine smooth muscle, the Ca-extrusion system of the intracellular free $\mathrm{Ca}$ might be activated in proportion to the progress of gestation. As a consequence, the free $\mathrm{Ca}$ concentration, raised by high $\mathrm{K}$, may be more rapidly decreased during the progress of gestation.

Much the same results were obtained on the free $\mathrm{Ca}$ concentration as estimated from contractions induced by $\mathrm{ACh}\left(1 \times 10^{-5} \mathrm{M}\right)$. However, the free $\mathrm{Ca}$ concentration during the $\mathrm{ACh}$-induced contraction seems always to be larger than for the $128 \mathrm{mM} \mathrm{K}$-induced contraction at any given stage of gestation. ACh produced phasic and tonic contractions at all stages in uterine smooth muscle. In Ca-free condition, the $\mathrm{ACh}$ induced phasic contraction became smaller, but persisted. On the other hand, tonic contraction was abolished, indicating that in physiological conditions, $\mathrm{ACh}$ produces contraction through the release of $\mathrm{Ca}$ from the intracellular store sites and influx of $\mathrm{Ca}$. The $\mathrm{ACh}$ induced contraction, in the presence or absence of $\mathrm{Ca}$, 
increased during the progress of gestation (Figures 1 and 6). It is not clear whether our results are solely due to increases in number of muscarinic receptors or due to increase in the $\mathrm{Ca}$ regulating system.

It is known that in cardiac, visceral and vascular smooth muscles, the Ca stored in the cell is released by caffeine (Ebashi \& Endo, 1968; Ebashi et al., 1977; Endo et al., 1977; Endo \& Kitazawa, 1978; Itoh et al., 1981; 1982; Kuriyama et al., 1982; Itoh et al., 1983; Kanmura et al., 1983) and this Ca release depends mainly on the Ca-induced $\mathrm{Ca}$ release mechanism, in vascular smooth muscles (Itoh et al., 1981; 1983) but the mechanism of $\mathrm{Ca}$ release from the store site by $\mathrm{ACh}$ differs from that by caffeine. In vascular and visceral muscle tissues, $\mathrm{ACh}$ activates the muscarinic receptor in the presence or absence of $\mathrm{Ca}$ and releases the $\mathrm{Ca}$ from the store sites, possibly via the phosphatidyl inositol turnover, which may promote release of Ca from the store sites (Berridge, 1984; Suematsu et al., 1984b).

\section{References}

ABE, Y. (1971). Effects of changing the ionic environment on passive and active membrane properties of pregnant rat uterus. J. Physiol., 214, 173-190.

ADELSTEIN, R.S. \& EISENBERG, E. (1980). Regulation and kinetics of the actin-myosin-ATP interaction. $A$. Rev. Biochem., 49, 921-956.

ADELSTEIN, R.S. \& KLEE, C.B. (1980). Smooth muscle myosin light chain kinase. In Calcium and Cell Function. Vol. 1, ed. Cheung, W.Y. pp. 167-179. New York, London, Toronto, Sydney, San Francisco: Academic Press.

ANDERSON, G.F., KAWARABAYASHI, T. \& MARSHALL, J.M. (1981). Effect of indomethacin and aspirin on uterine activity in pregnant rats; comparison of circular and longitudinal muscle. Biol.Reprod., 24, 359-372.

BERRIDGE, M.J. (1984). Inositol triphosphate and diacylglycerol as second messengers. Biochem. J., 220, $345-360$.

CASTEELS, R. \& KURIYAMA, H. (1965). Membrane potential and ionic content in pregnant and non-pregnant rat myometrium. J. Physiol., 177, 263-287.

DANIEL, E.E., CRANKSHAW, D. \& KWAN, C.Y. (1979). Intracellular sources of $\mathrm{Ca}$ for activation of smooth muscle. In Trends in Autonomic Pharmacology. pp. 443-484. Baltimore \& Munich: Urban \& Schwarzenberg.

DEVINE, C.E., SOMLYO, A.V. \& SOMLYO, A.P. (1972). Sarcoplasmic reticulum and excitation-contraction coupling in mammalian smooth muscles. J. cell. Biol., 52, 690-718.

EBASHI, S. \& ENDO, M. (1968). Calcium ion and muscle contraction. Prog. Biophys. mol. Biol., 18, 123-183.

EBASHI, S., MIKAWA, T., HIRATA, M., TOYOOKA, T. \& NONOMURA, Y. (1977). Regulatory proteins of smooth muscle. In Excitation-Contraction Coupling in Smooth
In conclusion, there was an increase in the absolute tension development per unit cross-sectional area and the Ca-sensitivity of the uterine smooth muscle cells of rats with the progress of gestation. It is suggested that these phenomena are mainly due to changes in the amount of contractile proteins. Furthermore, the ACh-induced contraction markedly increased in comparison with the spontaneous- and $128 \mathrm{mM} \mathrm{K}$-induced contractions during the progress of gestation. These differences may be related to changes in the properties of the $\mathrm{Ca}$ store site and/or agonist-stimulated $\mathrm{Ca}$ influxes.

This study was supported by the Ministry of Education in Japan. I am indebted to Prof. H. Kuriyama for guidance throughout this study, to Dr T. Itoh for pertinent encouragement and to Dr K.E. Creed for improving the manuscript.
Muscle. ed. Casteels, R., Godfraind, T. \& Rüegg, J.C. pp. 325-334. Amsterdam: Elsevier/North-Holland Biomedical Press.

EDMAN, K.A.P. \& SCHILD, H.O. (1962). The need for calcium in the contractile responses induced by acetylcholine and potassium in the rat uterus. J. Physiol., 161, 424-441.

ENDO, M. (1977). Calcium release from the sarcoplasmic reticulum. Physiol. Rev., 57, 71-108.

ENDO, M. \& KITAZAWA, T. (1978). Excitation-contraction coupling in chemically skinned fibres of cardiac muscle. In Proc. VIII World Congr. Cardiology. ed. Hayase, E. \& Murao, S. pp. 800-803. Amsterdam, Oxford, Princeton: Excepta Medica.

ENDO, M., KITAZAWA, T., YAGI, S., IINO, M. \& KAKUTA, Y. (1977). Some properties of chemically skinned smooth muscle fibers. In Excitation-Contraction Coupling in Smooth Muscle. ed. Casteels, R., Godfraind, T. \& Rüegg, J.C. pp. 199-209. Amsterdam: Elsevier/North-Holland Biomedical Press.

IINO, M. (1981). Tension responses of chemically skinned fibre bundles of the guinea-pig taenia caeci under varied ionic environments. J. Physiol., 320, 449-467.

ITOH, T., KAJIWARA, M., KITAMURA, K. \& KURIYAMA, H. (1982). Roles of stored calcium on the mechanical response evoked in smooth muscle cells of the porcine coronary artery. J. Physiol., 322, 107-125.

ITOH, T., KURIYAMA, H. \& SUZUKI, H. (1981). Excitationcontraction coupling in smooth muscle cells of the guinea-pig mesenteric artery. J. Physiol., 321, 513-535.

ITOH, T., KURIYAMA, H. \& SUZUKI, H. (1983). Differences and similarities in the noradrenaline- and caffeine-induced mechanical response in the rabbit mesenteric artery. J. Physiol., 337, 609-629.

KANMURA, Y., ITOH, T., SUZUKI, H., ITO, Y.\& KURIYAMA, H. (1983). Nifedipine actions on smooth muscle cells of 
pig and rabbit intact and skinned coronary arteries. In Asian-Pacific Adalat Symposium. ed. Hashimoto, K. \& Kawai, C. pp. 3-30. Tokyo: Medical Tribune Inc.

KAWARABAYASHI, T. \& OSA, T. (1976). Comparative investigations of alpha- and beta-effects on the longitudinal and circular muscles of the pregnant rat myometrium. Jap. J. Physiol., 26, 403-416.

KISHIKAWA, T. (1981). Alterations in the properties of the rat myometrium during gestation and postpartum. Jap. J. Physiol., 31, 515-536.

KURIYAMA, H., ITO, Y., SUZUKI, H., KITAMURA, K. \& ITOH, T. (1982). Factors modifying contraction-relaxation cycle in vascular smooth muscles. Am. J. Physiol., 243, H641-H662.

KURIYAMA, H. \& SUZUKI, H. (1976a). Changes in electrical properties of rat myometrium during gestation and following hormonal treatments. J. Physiol., 260, 315-333.

KURIYAMA, H. \& SUZUKI, H. (1976b). Effects of prostaglandin $E_{2}$ and oxytocin on the electrical activity of hormonetreated and pregnant rat myometria. J. Physiol., 260, 335-349.

LALANNE, C., MIRONNEAU, C., MIRONNEAU, J. \& SAVINEAU, J.P. (1984). Contractions of rat uterine smooth muscle induced by acetylcholine and angiotensin II in $\mathrm{Ca}^{2+}$-free medium. Br. J. Pharmac., 81, 317-326.

MATTOS, C.E.R., KEMPSON, R.L., ERDOS, T. \& CSAPO, A. (1967). Stretch-induced myometrial hypertrophy. Fertil. Steril., 18, 545-556.

MATSUI, K., HIGASHI, K., FUKUNAGA, K., MIYAZAKI, K., MAEYAMA, M. \& MIYAMOTO, E. (1983). Hormone treatments and pregnancy alter myosin light chain kinase and calmodulin levels in rabbit myometrium. J. Endocrinol., 97, 11-19.

MICHAEL, C.A. \& SCHOFIELD, B.M. (1969). The influence of the ovarian hormones on the actomyosin content and the development of tension in uterine muscle. J. Endocrinol., $44,501-511$.
OSA, T. \& KAWARABAYASHI, T. (1977). Effects of ions and drugs on the plateau potential in the circular muscle of pregnant rat myometrium. Jap. J. Physiol., 27, 111-112.

OSA, T. \& OGASAWARA, T. (1983). Effects of magnesium on the membrane activity and contraction of the circular muscle of rat myometrium during late pregnancy. Jap. $J$. Physiol., 33, 485-495.

OSA, T., OGASAWARA, T. \& KATO, S. (1981). Modification by magnesium and manganese ions of the effects of oxytocin on the electrical and mechanical activity of the longitudinal muscle of estrogen treated rat uterus. Jap. J. Physiol., 31, 317-329.

OSA, T., OGASAWARA, T. \& KATO, S. (1983). Effects of magnesium, oxytocin, and prostaglandin $F_{2 \alpha}$ on the generation and propagation of excitation in the longitudinal muscle of rat myometrium during late pregnancy. Jap. J. Physiol., 33, 51-67.

OSA, T. \& WATANABE, M. (1978). Effects of catecholamines on the circular muscle of rat myometria at term during pregnancy. Jap. J. Physiol., 28, 647-658.

RUEGG, J.C., MEISHERI, K., PFITZER, G. \& ZEUGNER, C. (1983). Skinned coronary smooth muscle: calmodulin, calcium antagonists and cAMP influence contractility. Basic Res. Cardiol., 78, 462-471.

SAIDA, K. (1982). Intracellular Ca release in skinned smooth muscle. J. gen. Physiol., 80, 191-202.

SUEMATSU, E., HIRATA, M. \& KURIYAMA, H. (1984a). Effects of cAMP- and cGMP-dependent protein kinases, and calmodulin on $\mathrm{Ca}^{2+}$ uptake by highly purified sarcolemmal vesicles of vascular smooth muscle. Biochim. biophys. Acta., 773, 83-90.

SUEMATSU, E., HIRATA, M., HASHIMOTO, T. \& KURIYAMA, H. (1984b). Inositol 1, 4, 5-trisphosphate released $\mathrm{Ca}^{2+}$ from intracellular store sites in skinned single cells of porcine coronary artery. Biochem. biophys. Res. Commun., 120, 481-485. 